\title{
HUBUNGAN DI ANTARA FAKTOR DEMOGRAFI DENGAN PENENTUAN KADAR HANTARAN: KAJIAN DI PERLIS, KEDAH, PULAU PINANG DAN PERAK*
}

\author{
Raihanah Azahari** \\ Khairun Najmi Saripudin ${ }^{* * *}$ \\ Raihana Abd Wahab ${ }^{* * * *}$
}

\begin{abstract}
This article focuses on the issue of hantaran according to the practice by Malay muslim community in Malaysia. The aim of the study is to identify relations between demografic factor such as level of education, education background and the income with the rate of the hantaran. This article also try to identify the relevance rate of hantaran which will be implemented by the community nowadays. To collect the data, methods of library research and questionnaire survey were used. Data from the questionnaire were prosesed by using SPSS 12. Two type of statistics have been used to describe the data into frequency, percentage, crosstabulation and chi-square. Result shows that only the level of education and education background was significance correlatively to determine high or low rate of the hantaran.
\end{abstract}

Keywords: Hantaran, Malay Custom, Dowry, Islamic Marriage, Munakahat

Artikel ini dihasilkan dari peruntukan PJP FS153/2008C (Geran Khas Universiti Penyelidikan)

** Profesor Madya, Jabatan Fiqh \& Usul, Akademi Pengajian Islam, Universiti Malaya, Kuala Lumpur.

*** Pembantu Penyelidik, Jabatan Fiqh \& Usul, Akademi Pengajian Islam, Universiti Malaya, Kuala Lumpur.

***** Pembantu Penyelidik, Jabatan Fiqh \& Usul, Akademi Pengajian Islam, Universiti Malaya, Kuala Lumpur. 


\section{PENGENALAN}

Dalam amalan perkahwinan masyarakat Melayu di Malaysia pada dasarnya ia terikat kepada dua keadaan, iaitu hukum syara' yang dikuatkuasakan melalui Enakmen Undang-undang Keluarga Islam di setiap negeri dan adat resam masyarakat setempat. Kesan daripada itu lahirnya dua amalan dalam perkahwinan masyarakat Melayu, iaitu mahar dan hantaran. Kedua-dua amalan tersebut berbeza dari sudut pengamalannya di antara negeri-negeri di Malaysia dan mempunyai konsepnya yang tersendiri menurut budaya masyarakat setempat. Mas kahwin atau mahar ialah pemberian wajib dari lelaki kepada wanita dan ia menjadi hak mutlak pengantin perempuan. Hantaran pula merupakan hadiah pemberian daripada pihak pengantin lelaki kepada pengantin perempuan dan bergantung kepada kemampuan mereka. Pada asasnya, hantaran bukanlah hak mutlak kaum wanita malah ia kerapkali dibelanjakan untuk mengadakan majlis perkahwinan.

Persoalannya sekarang ialah, masyarakat nampaknya telah terkeliru dalam memberikan nilai kepada mahar dan hantaran. Masyarakat kini lebih mengutamakan hantaran daripada mahar, menyebabkan ada segelintir keluarga pihak perempuan sengaja meletakkan kadar hantaran terlalu tinggi sehingga puluhan ribu ringgit. Persoalannya apakah asas atau faktor yang menjadi sandaran dalam penetapan kadar hantaran tersebut. Apakah faktorfaktor demografi seperti tahap pendidikan, aliran pendidikan dan kadar pendapatan mempunyai hubungan dalam menentukan nilai tinggi atau rendah hantaran. Meskipun bentuk dan kadar hantaran tidak ditentukan oleh masyarakat, namun apakah kadar yang sesuai dan munasabah diamalkan dalam pemberian hantaran, supaya ia tidak merugikan pihak yang menerima dan tidak membebankan pihak yang memberi?

\section{ARTIKEL INI BERTUJUAN UNTUK}

1. Mengenalpasti faktor-faktor yang mempengaruhi penentuan kadar hantaran

2. Mengenalpasti kadar hantaran yang sesuai dan munasabah diamalkan 


\section{METODOLOGI KAJIAN}

Bagi tujuan pengumpulan data, metod perpustakaan menjadi asas dalam mengolah persoalan pokok mengenai hantaran. Metod ini digunakan untuk mengenal pasti pengertian dan konsep adat hantaran menurut Islam dan budaya masyarakat Melayu. Untuk memperolehi data yang berkaitan dengan persepsi masyarakat serta amalan dalam penentuan hantaran satu soal selidik telah dibentuk. Soal selidik ini merangkumi latarbelakang demografi responden dan kadar hantaran yang telah ditetapkan. Soal selidik ini dijalankan dengan mengambil masyarakat Melayu muslim di negeri-negeri Perlis, Kedah, Pulau Pinang dan Perak sebagai responden. Negeri-negeri ini dipilih untuk kerana persepsi masyarakat menganggap bahawa hantaran bagi mereka yang berasal dari utara adalah tinggi. Daripada soal selidik ini maklumat dan data yang berkaitan dengan masalah kajian akan diperolehi. Kesemua data-data empirikal yang telah dikumpul dianalisis menggunakan SPSS versi 12.0. Analisis yang dibuat bukan sahaja mengenalpasti amalan hantaran dalam masyarakat Melayu tetapi juga mengenalpasti bagaimana pembolehubahpembolehubah yang dinyatakan mempunyai hubungan dengan penentuan hantaran.

\section{ULASAN LITERATUR}

Terdapat penulisan-penulisan yang membincangkan mengenai adat hantaran menurut perspektif Islam dan sosio budaya masyarakat Melayu seperti Adat Resam Dan Adat Istiadat Melayu tulisan Syed Alwi Sheikh al-Hadi, Istiadat Perkahwinan Melayu, Satu Kajian Perbandingan tulisan Amran Kasimin. Perbincangan mengenainya banyak difokuskan dari sudut persepsi amalan dan perlaksanaannya menurut budaya masyarakat Melayu tradisional. Selain daripada itu ia juga menyentuh dari aspek sejarah dan pengaruh budaya 
asing dalam adat resam perkahwinan masyarakat Melayu serta pengambilkiraan pandangan Islam tentang adat-adat tersebut. ${ }^{1}$

Selain daripada tulisan-tulisan tersebut, sudah terdapat banyak kajian yang telah dibuat di peringkat Sarjana dan Sarjana Muda mengenai hantaran dalam perkahwinan masyarakat Melayu. Di antara tajuk-tajuk yang telah dibuat dalam kajian diperingkat sarjana ialah Mahar dan hantaran Dalam Perkahwinan: Satu Kajian Terhadap Amalannya di Daerah Kuala Berang, Trengganu oleh Wan Bazli Fariz, "Mahar Dan Hantaran: Satu Tinjauan Di Daerah Alor Gajah, Melaka" tulisan Azizah binti Yusuf dan "Mahar Dan Hantaran: Amalannya Di Kalangan Masyarakat Melayu. Satu Kajian Di Daerah Kota Setar, Kedah" tulisan Mahyuddin Abu Bakar. ${ }^{4}$ Kajian-kajian tersebut menggunakan soal selidik dan temubual untuk mengumpul data-data primari. Data-data soal selidik dalam kajian tersebut dianalisis dengan menggunakan kaedah taburan kekerapan dan peratus. Meskipun perbincangan mengenai hantaran telah disentuh dari pelbagai aspek, namun masih terdapat ruang yang tidak disentuh secara terperinci dalam kajian-kajian lepas. Sehubungan itu, kajian-kajian dan tulisantulisan terdahulu merupakan bahan asas utama bagi memahami konsep hantaran menurut Islam dan budaya masyarakat Melayu. Di samping itu, kajian ini juga mengambil kira beberapa persoalan yang tidak disentuh secara terperinci dalam kajian lapangan yang telah dibuat sebelum ini, seperti pengambilkiraan faktor

1 Lihat perbincangan tentang tajuk "Adat Resam Nikah Kahwin”, dalam Syed Alwi Sheikh al-Hadi (1986), Adat Resam Dan Adat Istiadat Melayu, ed. ke 7. Kuala Lumpur: Dewan Bahasa \& Pustaka; Lihat "Pengaruh Luar Dalam Adat Istiadat Perkahwinan Orang Melayu" Amran Kasimin (1989), Istiadat Perkahwinan Melayu. Satu kajian Perbandingan. Kuala Lumpur: Dewan Bahasa \& Pustaka.

2 Wan Bazli Fariz bin Wan Bakar (2001), Mahar dan Hantaran Dalam Perkahwinan; Satu Kajian terhadap Amalannya di Daerah Kuala Berang, Terengganu, (Tesis Sarjana Jabatan Fiqh Dan Usul, APIUM).

3 Azizah Yusuf (1988), Mahar dan Hantaran: Satu tinjauan di Daerah Alor Gajah Melaka (Kertas Projek, Fakulti Syariah, APIUM).

4 Mahyuddin Abu Bakar (1998), Mahar Dan Hantaran: Amalannya Di Kalangan Masyarakat Melayu. Satu Kajian Di Daerah Kota Setar, Kedah, (Kertas Projek, Bahagian Pengajian Syariah, Akademi Pengajian Islam, Universiti Malaya). 
dalam penetapan kadar hantaran. Meskipun tajuk kajian yang dikemukakan hampir mempunyai persamaan dan pertalian secara langsung dengan kajian-kajian lapangan yang telah dibuat sebelum ini, ia tidaklah boleh disifatkan sebagai mengulangi kajian-kajian tersebut tetapi perlu dilihat dari aspek penelitian dan penganalisaan dokumentasi mengenai kajian-kajian yang terdahulu dalam bentuk pengolahan yang tersendiri mengikut skop dan metod kajian serta difokuskan kepada lokasi kajian yang berbeza. Artikel ini juga merupakan hasil dari kajian saintifik yang terkini bagi mengenalpasti pengamalan hantaran dalam masyarakat Melayu Muslim di Malaysia.

\section{HANTARAN MENURUT ISLAM DAN ADAT MELAYU}

Menurut Kamus Dewan hantaran bererti wang yang dihantar oleh pihak pengantin lelaki kepada bakal ibu mertua untuk perbelanjaan perkahwinan. Ia juga dikenali dengan istilah "belanja hangus". Hantaran juga disitilah sebagai hadiah perkahwinan. ${ }^{5}$ UndangUndang keluarga Islam Kedah dan Perak mentakrifkan hantaran sebagai hadiah samada dalam bentuk wang tunai atau barangan yang diberikan oleh suami kepada isterinya semasa majlis perkahwinan berlangsung. ${ }^{6}$ Di Pulau Pinang hantaran didefinisikan sebagai hadiah perkahwinan selain daripada wang tunai yang diberikan oleh suami kepada isterinya ketika perkahwinan dilangsungkan. ${ }^{7}$ manakala di Perlis hantaran bermaksud bayaran wajib perkahwinan yang diletakkan di bawah undang-undang Islam yang dibayar oleh pengantin lelaki kepada pengantin perempuan. ${ }^{8}$

Pada dasarnya hantaran merupakan sejumlah wang yang diberikan oleh pengantin lelaki kepada pihak perempuan sewaktu upacara perkahwinan. Meskipun berbeza maksud dan tujuannya berbeza menurut adat dan budaya masyarakat setempat tetapi amalannya adalah sama dengan maksud hadiah atau pemberian.

5 Tengku Iskandar (1997), Kamus Dewan, ed. ke 3. Kuala Lumpur: Dewan Bahasa \& Pustaka, h. 437.

6 Enakmen Undang-Undang Pentadbiran Ugama Islam Perak 1965, Enakmen Undang-Undang Pentadbiran Islam Kedah 1962

7 Enakmen Undang-Undang Pentadbiran Ugama Islam Pulau Pinang 1960

8 Enakmen Undang-Undang Pentadbiran Islam Perlis 1963 
Menurut istilah syarak, hadiah atau pemberian diistilahkan sebagai hibah. Hibah ialah suatu akad yang dapat memindah milik sesuatu objek tanpa perlu kepada gantian kerana dibuat secara sukarela. ${ }^{9}$

Adalah suatu yang sukar untuk menentukan latarbelakang kewujudan adat hantaran ini dalam masyarakat Melayu. Namun demikian tidak boleh dinafikan bahawa adanya pengaruh luar dalam adat istiadat perkahwinan Melayu khususnya pengaruh Hindu. Amalan ini telah bercampuraduk dengan amalan yang sedia ada dan ia akhirnya menjadi sebati dengan jiwa masyarakat Melayu dan di warisi dari generasi ke generasi. Kenyataan sejarah menunjukkan sebahagian daripada adat istiadat perkahwinan masyarakat Melayu mempunyai persamaan dengan adat istiadat yang diamalkan di kalangan masyarakat Islam di India. ${ }^{10}$ Salah satu adat tradisi yang diamalkan oleh masyarakat Islam India ialah majlis "menghantar belanja" yang dilakukan berasingan sebelum majlis akad nikah dijalankan. Selepas beberapa ketika, untuk menjimatkan masa dan wang majlis menghantar belanja ini dilakukan bersama pada hari pernikahan. ${ }^{11}$ Di bahagian utara India, majlis perkahwinan dilakukan dengan pertukaran hadiahhadiah yang dinamakan sachad. ${ }^{12}$ Kenyataan ini menjelaskan keberadaan adat hantaran dalam masyarakat Melayua adalah berasal dari tradisi yang diamalkan masyarakat India.

Oleh kerana hantaran merupakan adat resam yang lahir dari budaya masyarakat Melayu maka tidak terdapat nas syarak yang menjelaskan hukum beramal dengan amalan tersebut. Namun demikian dalam Islam adat merupakan salah satu sumber yang penting dalam pembinaan hukum syarak dalam perkara yang tidak dinaskan. Dalam konteks ini fuqaha telah menetapkan beberapa prinsip usulfiqh yang berkaitan dengan adat sehingga

Md Akhir Hj Yaacob (1990), Undang-undang Sivil Islam (terj.), Kuala Lumpur: DBP, hh. 50-51; Shams al-Dīn Muhammad bin Khātib Syarbinī (1997), Mughnī muhtāj ilā ma'rifati ma'ān̄̄ alfāzi al-minhāji, jil. 2. Beirut:Dār ma'rifah, h. 512.

10 Amran Kasimin (1989), Adat Istiadat Perkahwinan Melayu, Satu Kajian Perbandingan. Kuala Lumpur: DBP, hh. 50-51.

11 Ibid., h. 66.

12 Ibid. 
lahirnya beberapa kaedah fiqh ${ }^{13}$ yang menjadi asas pembinaan

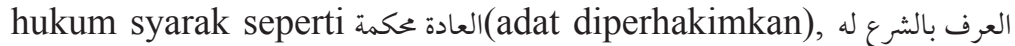

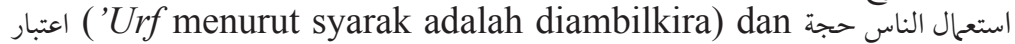
(amalan manusia diambilkira sebagai hujjah yang wajib diamalkannya). Pada dasarnya syarak telah menetapkan beberapa syarat mengenai kedudukan adat sebagai asas penentuan hukum iaitu: ${ }^{14}$

- Adat tersebut tidak menyalahi hukum syarak dari aspek amalan dan pelaksanaannya

- Adat tersebut diamalkan dan diterima majoriti dalam sesuatu masyarakat

- Adat tersebut sudah wujud dan diwarisi zaman berzaman

- Adat tersebut diterima pakai dan diamalkan oleh generasi terkemudian.

Adat didefinisikan sebagai suatu perkara yang telah mantap dalam jiwa manusia dari segi akal fikiran serta diterima oleh tabiat yang sejahtera. Adat hantaran dalam amalan perkahwinan masyarakat Melayu merupakan salah satu tradisi yang diamalkan sejak turun temurun lagi. Oleh yang demikian amalan tersebut dianggap sebagai satu ciri adat resam dalam budaya perkahwinan masyarakat Melayu. Dari segi kedudukan syarat-syarat yang telah ditetapkan oleh syarak sebagai asas penentuan hukum yang tidak dinaskan, adat hantaran pada dasarnya memenuhi syarat-syarat yang ditetapkan iaitu:

- Adat hantaran tidak menyalahi hukum syarak kerana amalannya berasaskan konsep hadiah atau pemberian

- Adat hantaran diterima dan diamalkan oleh majoriti masyarakat Melayu di Malaysia

13 Ahmad bin Muhammad al-Zarqā (1989), Syarh al-Qawā'id alFiqhiyyah. cet. 2. Damsyik: Dār al-Qalam, hh. 219-222, 223.

14 Md Saleh Hj Md@Hj Ahmad (2006), "Urf dan Adat Semasa di Malaysia Sebagai Asas Penentuan Hukum Yang Tidak di Naskan", dalam Md Saleh Hj Md @ Hj Ahmad (et.al.), Hukum Islam dan Budaya Termpatan. Kuala Lumpur: APIUM, h. 483. 
- Adat hantaran merupakan amalan masyarakat Melayu yang diwarisi dan dipertahankan dari generasi ke generasi sejak turun temurun

- Adat hantaran merupakan amalan tradisi yang masih kekal diamalkan dan disanjug tingi oleh Masyarakat Melayu sehingga kini.

Dalam masyarakat Melayu hantaran diamalkan menurut adat resam setempat yang berbeza. Perbezaan ini berlaku bukan sahaja dalam penyediaan barang-barang hantaran tetapi juga dalam penetapan kadar wang hantaran. Antara faktor yang boleh mempengaruhi penetapan kadar wang hantaran ini ialah kedudukan keluarga, latar belakang pendidikan serta taraf ekonomi seseorang.

\section{ANALISIS}

Analisis data akan dibincangkan dalam dua bentuk iaitu:

1. Taburan kekerapan dan peratus yang melibatkan latar belakang responden

2. Hubungan antara penetapan kadar mahar dengan faktor demografi. Faktor demografi yang diandaikan mempunyai hubungan dengan penetapan kadar hantaran ialah kadar pendapatan bulanan, taraf dan aliran pendidikan. Aras signifikan yang diguna pakai dalam ujian ini ialah 0.05. Keputusan ujian yang melepasi aras tersebut dianggap tidak mempunyai hubungan antara pembolehubah dengan faktor demografi. Ujian yang dilakukan adalah untuk menguji hipotesis:

a- Ho: Terdapat hubungan yang signifikan antara penetapan kadar hantaran dengan tahap pendidikan responden.

Ha: Tidak terdapat hubungan yang signifikan antara penetapan kadar hantaran dengan tahap pendidikan responden.

b- Ho: Terdapat hubungan yang signifikan antara penetapan kadar hantaran dengan faktor pendapatan.

Ha: Tidak terdapat hubungan yang signifikan antara penetapan kadar hantaran dengan faktor pendapatan. 
c- Ho: Terdapat hubungan yang signifikan antara penetapan kadar hantaran dengan dengan faktor aliran pendidikan

Ha: Tidak terdapat hubungan yang signifikan antara penetapan kadar hantaran dengan faktor aliran pendidikan

\section{Maklumat Demografi Responden}

Kajian ini melibatkan 416 orang responden sebagai sample yang terdiri daripada kalangan Melayu muslim di negeri Perlis, Kedah, Pulau Pinang dan Perak. Daripada jumlah tersebut 141 orang atau 33.9 peratus adalah responden lelaki dan 275 orang atau 66.1 peratus adalah responden perempuan. Jadual 1 menunjukkan taburan responden mengikut jantina.

Jadual 1: Taburan responden mengikut jantina

\begin{tabular}{ccc}
\hline Jantina & Kekerapan & Peratus \\
\hline Lelaki & 141 & 33.9 \\
Perempuan & 275 & 66.1 \\
\hline
\end{tabular}

Sumber: Borang Soal Selidik

Jadual 2 di bawah menunjukkan taraf perkahwinan responden. Dapatan kajian menunjukkan hampir keseluruhan responden iaitu 410 orang atau 98.6 peratus terdiri dari mereka yang masih dalam ikatan perkahwinan. Hanya 6 orang atau 1.5 peratus dari responden terdiri dari duda dan janda. Kajian ini pada dasarnya memfokuskan kepada responden yang telah berkahwin untuk mendapatkan data-data terkini dan tepat mengenai hantaran kerana responden memberi pandangan berdasarkan amalan dalam perkahwinan mereka.

Jadual 2: Taraf Perkahwinan Responden

\begin{tabular}{ccc}
\hline Taraf Perkahwinan & Kekerapan & Peratus \\
\hline berkahwin & 410 & 98.6 \\
duda & 2 & .5 \\
janda & 4 & 1.0 \\
\hline
\end{tabular}

Sumber: Borang Soal Selidik 
Dari aspek peringkat umur responden, majoritinya terdiri dari mereka yang berumur di antara 21-40 tahun. Jadual 3 di bawah menjelaskan secara detil peringkat umur responden.

Jadual 3: Peringkat Umur

\begin{tabular}{ccc}
\hline Umur & Kekerapan & Peratus \\
\hline bawah 20 tahun & 5 & 1.2 \\
21-30 tahun & 158 & 38.0 \\
31-40 tahun & 120 & 28.8 \\
41-50 tahun & 98 & 23.6 \\
51-60 tahun & 29 & 7.0 \\
61 tahun keatas & 6 & 1.4 \\
\hline
\end{tabular}

Sumber: Borang Soal Selidik

Jadual 4 di bawah merujuk kepada kadar pendapatan responden. Dapatan menunjukkan kebanyakan responden iaitu 242 orang terdiri dari mereka yang berpendapatan di antara RM1501 sehingga RM3500. Begitu pun terdapat 64 responden atau 13.7 peratus yang berpendapatan di antara RM500 - RM1000.

Jadual 4: Kadar Pendapatan

\begin{tabular}{ccc}
\hline Kadar Pendapatan & Kekerapan & Peratus \\
\hline Bawah 500 & 16 & 3.9 \\
RM500-RM1000 & 64 & 15.4 \\
RM1001-RM1500 & 31 & 7.5 \\
RM1501-RM2000 & 55 & 13.3 \\
RM2001-RM2500 & 62 & 14.9 \\
RM2501-RM3000 & 75 & 18.1 \\
RM3001-RM3500 & 50 & 12.0 \\
RM3501-RM4000 & 20 & 4.8 \\
RM4001-RM4500 & 19 & 4.6 \\
RM4501-RM5000 & 8 & 1.9 \\
RM5001-RM5500 & 5 & 1.2 \\
RM 5501-RM6000 & 3 & .7 \\
RM6000 keatas & 7 & 1.7 \\
\hline
\end{tabular}

Sumber: Borang soal selidik 
Kajian juga melibatkan aspek tahap pendidikan responden. Dapatan kajian menunjukkan majoriti responden terdiri dari mereka yang berpendidikan diperingkat Ijazah Sarjana Muda 40.9 peratus (170) diikuti mereka yang berpendidikan SPM 99 orang atau 23.8 peratus. Dapatan ini adalah selaras dengan jumlah pendapatan bulanan bagi setiap responden. Dapatan kajian di tunjukkan dalam jadual 5.

Jadual 5: Tahap Pendidikan

\begin{tabular}{lcc}
\hline Tahap Pendidikan & Kekerapan & Peratus \\
\hline Tidak pernah mengikuti & 8 & 1.9 \\
pengajian formal & 3 & 0.7 \\
UPSR & 10 & 2.4 \\
PMR/SRP & 99 & 23.8 \\
SPM & 33 & 7.9 \\
STPM & 22 & 5.3 \\
Sijil & 50 & 12.0 \\
Diploma & 1 & .2 \\
Matrikulasi & 170 & 40.9 \\
Ijazah Sarjana Muda & 18 & 4.3 \\
Sarjana & 2 & 0.5 \\
PhD & & \\
\hline
\end{tabular}

Sumber: Borang Soal Selidik

Aliran pendidikan dikategorikan kepada dua iaitu aliran umum dan aliran agama. Kategori ini adalah bersesuaian dengan permasalahan kajian iaitu untuk melihat perbezaan dan hubungan antara pemboleh-pemboleh ubah dalam ujian dua hala dan ujian khi kuasa dua. Dapatan kajian menunjukkan majoriti responden 73.7 peratus mempunyai latar belakang pendidikan umum manakala selebihnya 23.3 peratus beraliran pendidikan agama. Taburan aliran pendidikan responden ditunjukkan dalam jadual 6 . 
Jadual 6: Aliran Pendidikan

\begin{tabular}{lcc}
\hline Tahap Pendidikan & Kekerapan & Peratus \\
\hline Aliran agama & 109 & 26.3 \\
Aliran umum & 307 & 73.7 \\
\hline
\end{tabular}

Sumber: Borang Soal Selidik

\section{Hubungan Di antara Faktor Demografi dengan Penetapan Kadar Hantaran}

\subsection{Hubungan Di antara Faktor Tahap Pendidikan dangan Penetapan Kadar Mahar}

Jadual 7 menunjukkan hasil ujian signifikan khi-kuasa dua yang diperolehi mencatatkan keputusan $\mathrm{X}(9)=172.942, \mathrm{P}<0.05$ yang menunjukkan Ho diterima. Berdasarkan keputusan tersebut ia menunjukkan bahawa terdapatnya hubungan yang signifikan antara kadar hantaran dan faktor tahap pendidikan. Dapatan kajian juga menunjukkan (Jadual 8) kadar mahar bagi responden yang berpendidikan di peringkat Ijazah Sarjana Muda ialah di antara RM2000 - RM10000. Manakala kadar mahar bagi responden yang berpendidikan di peringkat SPM dan Diploma ialah di antara RM1000 - RM6000. Dapatan ini juga menunjukkan bahawa semakin tinggi tahap pendidikan seseorang semakin tinggi nilai hantaran yang ditetapkan. Berdasarkan keputusan ujian ini menunjukkan faktor tahap pendidikan boleh mempengaruhi penetapan kadar hantaran dalam perkahwinan.

Jadual 7: Keputusan Ujian Signifikan Khi-Kuasa Dua Antara

Penetapan Kadar Hantaran Dengan Tahap Pendidikan

\begin{tabular}{ll}
\hline Kadar Hantaran/Faktor Demografi & Keputusan Ujian \\
\hline Kadar Hantaran/Tahap Pendidikan & $\mathrm{X} 2(9)=172.942$, \\
& $\mathrm{P}<0.05$ \\
\hline
\end{tabular}

Sumber: Borang Soal Selidik 
Hubungan Di Antara Faktor Demografi Dengan Penentuan Kadar Hantaran

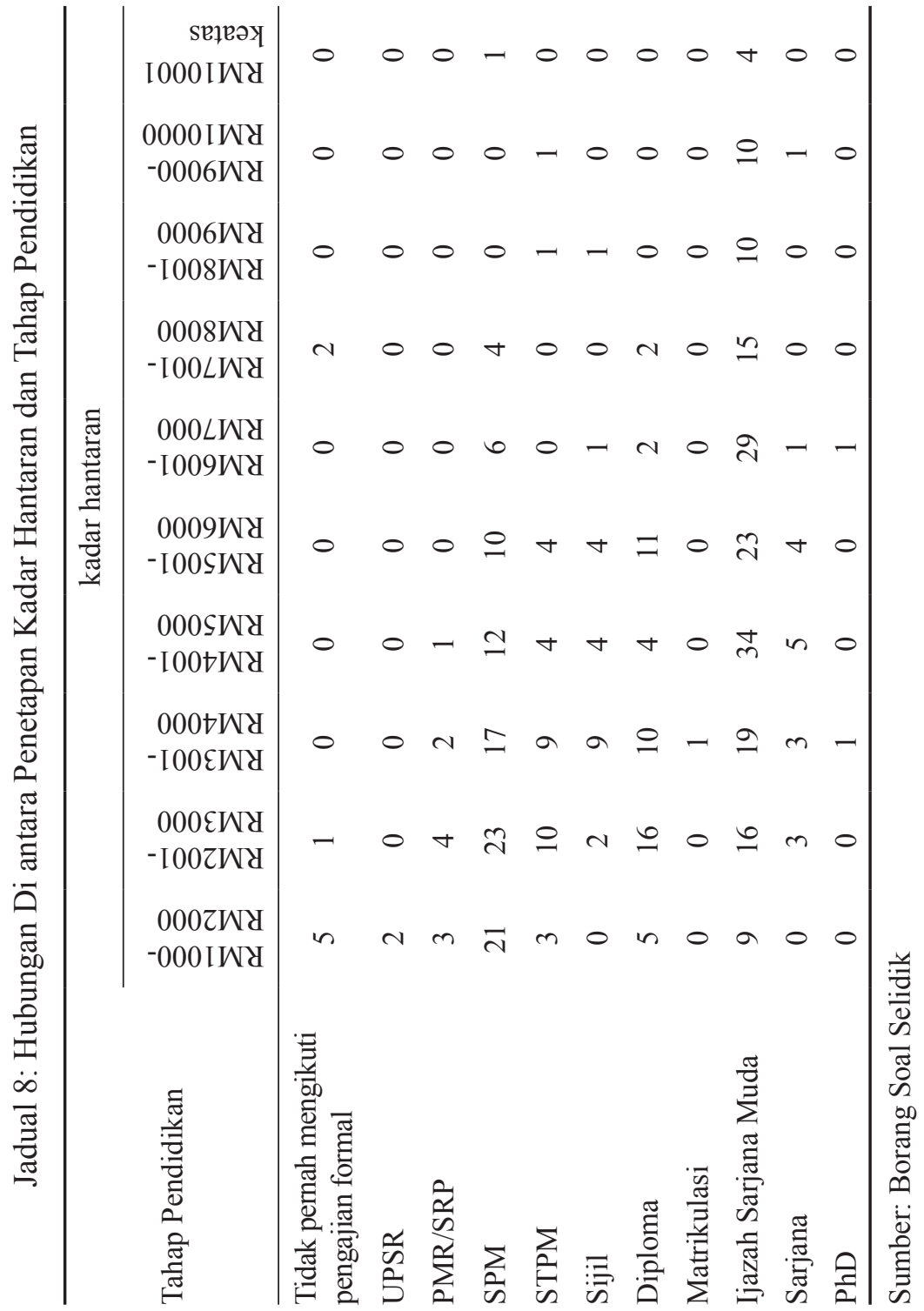




\subsection{Hubungan Di antara Penetapan Kadar Mahar dengan} Faktor Aliran Pendidikan

Jadual 9 menunjukkan hasil ujian signifikan khi-kuasa dua yang diperolehi mencatatkan keputusan $\mathrm{X}(9)=19.030, \mathrm{P}<0.05$ yang menunjukkan Ho diterima. Berdasarkan keputusan tersebut menunjukkan terdapat hubungan yang signifikan antara kadar hantaran dengan faktor aliran pendidikan. Dapatan kajian ini juga menunjukkan faktor aliran pendidikan boleh mempengaruhi penetapan kadar hantaran dalam perkahwinan. Dapatan dalam jadual 10 menunjukkan tiada perbezaan ketara di antara mereka yang beraliran pendidikan umum atau aliran pendidikan agama dalam penentuan kadar hantaran.

Jadual 9: Keputusan Ujian Khi-kuasa Dua

\begin{tabular}{cc}
\hline Kadar Hantaran/Faktor Demografi & Keputusan Ujian \\
\hline Kadar Hantaran/Aliran Pendidikan & $\begin{array}{c}\mathrm{X}(9)=19.030 \\
\mathrm{P}<0.05\end{array}$
\end{tabular}

Sumber: Borang Soal Selidik

Jadual 10: Hubungan Di antara Faktor Aliran Pendidikan dengan Penetapan Kadar Mahar

\begin{tabular}{|c|c|c|c|c|c|c|c|c|c|c|}
\hline \multirow[b]{2}{*}{ 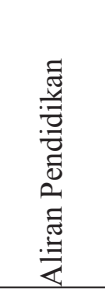 } & \multicolumn{10}{|c|}{ Kadar Hantaran } \\
\hline & 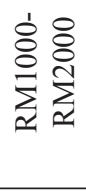 & 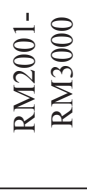 & $\begin{array}{l}\frac{1}{8} 8 \\
8 \\
\sum_{2}^{\infty} \sum_{\alpha}^{+1}\end{array}$ & $\begin{array}{l}\frac{1}{8} 8 \\
8 \\
\sum_{\simeq 1}^{+} \sum_{\Omega}^{n}\end{array}$ & 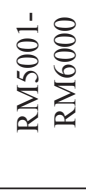 & $\begin{array}{l}\frac{1}{8} 8 \\
8 \\
\sum_{2}^{0} \sum_{\alpha}\end{array}$ & $\begin{array}{l}\frac{1}{8} 8 \\
8 \\
\sum \sum_{\Omega}^{\infty}\end{array}$ & $\begin{array}{l}\frac{1}{8} 8 \\
8 \\
\sum_{2}^{\infty} \sum_{1}^{\infty}\end{array}$ & 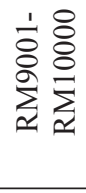 & 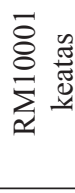 \\
\hline $\begin{array}{l}\text { Aliran } \\
\text { Agama }\end{array}$ & 10 & 14 & 12 & 15 & 22 & 17 & 8 & 3 & 5 & 1 \\
\hline $\begin{array}{l}\text { Aliran } \\
\text { Umum }\end{array}$ & 37 & 61 & 59 & 49 & 34 & 23 & 15 & 9 & 7 & 4 \\
\hline
\end{tabular}

Sumber: Borang Soal Selidik 


\subsection{Hubungan Di antara Penetapan Kadar Mahar dengan Faktor Kadar Pendapatan}

Jadual 11 menunjukkan hasil ujian signifikan khi-kuasa dua yang diperolehi mencatatkan keputusan X $(10)=10.596, \mathrm{P}>0.05$ yang menunjukkan Ho ditolak. Keputusan tersebut menunjukkan tidak terdapat hubungan yang signifikan antara penetapan kadar mahar dengan kadar pendapatan bulanan. Dapatan ini membuktikan bahawa faktor pendapatan bulanan tidak mempengaruhi penetapan kadar hantaran. Ini bermaksud, meskipun pendapatan responden adalah rendah tidak semestinya kadar hantaran yang ditetapkan rendah juga, berkemungkinan kadar hantaran tersebut lebih tinggi dari mereka yang berpendapatan tinggi dan sebaliknya jika responden berpendapatan tinggi tidaklah semestinya kadar kadar hantaran juga tinggi. (Lihat Jadual 12). Dalam hal ini, terdapat kemungkinan mereka yang berpendapatan rendah dibiayai oleh ahli keluarga atau ibu bapa dalam soal hantaran.

Jadual 11: Keputusan Ujian Khi-kuasa Dua

\begin{tabular}{cc}
\hline $\begin{array}{c}\text { Kadar Hantaran/Faktor } \\
\text { Demografi }\end{array}$ & Keputusan Ujian \\
\hline Kadar Hantaran/Kadar Pendapatan & $\mathrm{X}(10)=105.867$, \\
$\mathrm{P}>0.05$
\end{tabular}

Sumber: Borang Soal Selidik 


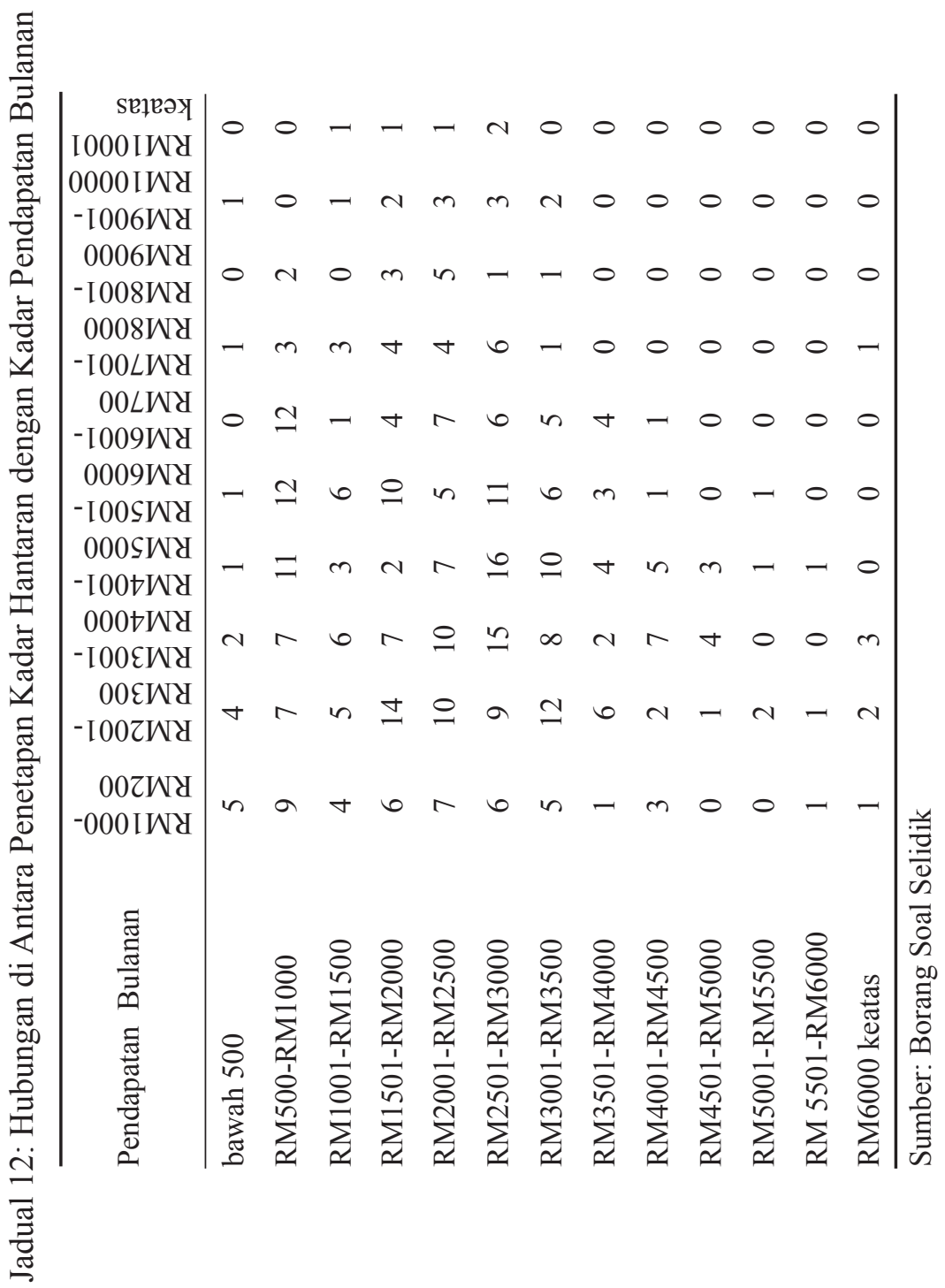




\section{KADAR WANG HANTARAN YANG MUNASABAH PADA MASA KINI}

Jadual 13 di bawah menunjukkan persepsi responden terhadap kadar wang hantaran yang sesuai diamalkan pada masa kini. Kebanyakan responden berpendapat kadar wang hantaran yang munasabah pada masa kini ialah di antara RM5000 - RM8000. Realitinya kadar hantaran pada masa kini telah jauh kehadapan dan bersesuaian dengan perkembangan ekoonomi semasa. Malahan dalam beberapa keadaan ia sudah melampaui kadar yang munasabah jika dibandingkan dengan kadar mahar terutamanya bagi negeri-negeri yang mas kahwinnya ditetapkan oleh Jabatanjabatan Agama Islam Negeri. Meskipun ia bukanlah suatu yang dihalang, tetapi adalah lebih wajar kadar mas kahwin dinilai kembali kerana ia merupakan hak mutlak wanita tetapi hantaran hanya merupakan hadiah atau pemberian dan bukan hak mutlak wanita yang kerapkali digunakan untuk belanja perkahwinan. Jelasnya, wang hantaran tidak banyak memberi faedah kepada wanita.

Jadual 13: Kadar Wang Hantaran Yang Munasabah

\section{Kadar Hantaran Yang Munasabah Kekerapan Peratus}

\begin{tabular}{lcc}
\hline RM1000 - RM 2000 & 11 & 2.7 \\
RM 2001 - RM 3000 & 13 & 3.2 \\
RM 3001 - RM 4000 & 11 & 2.7 \\
RM 4001 - RM 5000 & 36 & 8.7 \\
RM 5001 - RM 6000 & 78 & 18.9 \\
RM 6001 - RM 7000 & 70 & 17.0 \\
RM 7001 - RM 8000 & 90 & 21.8 \\
RM 8001 - RM 9000 & 44 & 10.7 \\
RM 9000 - RM10000 & 42 & 10.2 \\
RM 10001 ke atas & 17 & 4.1 \\
\hline
\end{tabular}

Sumber: Borang Soal Selidik 


\section{KESIMPULAN}

Hasil analisis yang dibuat, menunjukkan hanya faktor-faktor aliran pendidikan dan tahap pendidikan yang mempunyai signifikan dengan penetapan kadar hantaran. Ini bermakna faktorfaktor tersebut mempengaruhi penetapan kadar hantaran dari segi tinggi atau rendahnya. Manakala kadar pendapatan bulanan tidak mempengaruhi penetapan kadar hantaran. Analisis juga menunjukkan bahawa kebanyakan responden berpendapat bahawa kadar hantaran yang munasabah pada masa kini ialah di antara RM5000 - RM8000. Kadar ini mungkin bersesuaian dengan keadaan semasa ekonomi dan ianya kemungkinan dipengaruhi juga oleh maksud atau tujuan dalam penggunaan hantaran. Pihak yang menerima hantaran bermungkinan memerlukan kadar yang agak tinggi bagi tujuan mengadakan majlis perkahwinan. 